\title{
Factors Affecting Economic Performance of SMEs in Mongolia
}

\author{
Gandi Dagvadori ${ }^{*} \quad$ Zhan $\mathrm{Yu} \mathrm{Bo}^{2}$ \\ 1.School of Economics, Shanghai University, 99 Shangda Road, Shanghai 200444, China \\ 2.Shanghai Academy of Social Sciences, 7/622 Huaihai Zhonglu, Shanghai 200233, China
}

\begin{abstract}
The performance of Small Medium Enterprises (SMEs) play important role in economic development of a country, and it has been widely discussed that SMEs are the driving engine of economic development. In other words, by growth of SMEs, economy will be diversified, private sectors will be strengthened, unemployment will be decreased, technology and production will be improved. For SMEs in order to grow, sustainable economic performance is needed. The aim of this study is to identify the main factors affecting the economic performance of SMEs in Mongolia, make recommendation to improvement of the economic performance so that SMEs in Mongolia further influence the growth. This study uses data collected from World Bank Enterprise survey, and will use quantitative method to analyze the factors affecting the economic performance. The result of the study will be helpful for SMEs to orient itself and for policy makers.
\end{abstract}

Keywords: Small \& Medium Enterprises (SMEs), Mongolia, Economic Performance

DOI: $10.7176 / \mathrm{EJBM} / 11-21-16$

Publication date:July $31^{\text {st }} 2019$

\section{Introduction}

1.1 Research Background

Small and medium enterprises (SMEs) have an important role in the economy in almost all countries around the world. SMEs make up nearly $98 \%$ of all enterprises in Mongolia ( $80 \%$ above are microenterprises) yet their contribution to GDP is accounted as 25\% (World Bank 2015). From 2010 to 2013, there recorded 30 percent of increase in number of registered active enterprises in Mongolia (World Bank 2015). The National Statistics office of Mongolia does not make data available solely on SMEs but instead produce data on all business entities in Mongolia including large to small entities. The Government of Mongolia has declared law on SMEs and its official definition. SME law was adopted in 2007, to improve the consistency and effectiveness of government support programs. The government has been actively pursuing to develop and promote the Small Medium Enterprises in Mongolia that SMEs are driving force of addressing the difficulties of unemployment, economic diversification and inequality.

Some scholars who have researched earlier the various factors that have influence on firm performance are Hanks,1994; Zahra and George, 1999; Covin 1991. Performance measurement for SMEs is still not well established although there are numerous studies on SMEs. The purpose of this paper is to identify the factors affect and drive the economic performance of SME. Several factors have been identified as factors affect the economic performance such as age, capital, labor, cost of labor, access to finance, export thus will be studied in this paper.

\section{Literature Review}

This section will provide a brief review of the factors that affect SME performance, particularly economic performance. Chosen variables for SMEs in Mongolia and based from the enterprise survey: age (firm characteristic), capital, labor, cost of labor, access to finance, export (trade).

\subsection{Age (Firm characteristics)}

One of the earliest literature by Sutton (1997) study based on law of proportionate effect which implies the possibility of any active firm getting new opportunity is proportional to the current size of the firm. Scholar Haltiwanger et al (2013) empirical findings suggest that both age and size are important factors to be considered, and the age variable plays more important role in employment growth dynamics. Their findings suggested that being small is the key to job creation. The start-ups and young firms are essential sources of growth and productivity.

\subsection{Capital}

In literature, the concept of capital is used for financial assets, such as funds held in deposit account, also physical factors of production, manufacturing equipment, facilities and including buildings used for produce and store manufactured goods. There are variety of functional forms to describe the production, one of the classic form is Cobb-Douglas, keeping in mind it establishes the importance of value of capital, current value of of plant machinery, production buildings. As scholar Barney (1991) defined firm's resource divided into three groups: (1) physical capital including technology, plant equipment location and access to raw material, (2) human capital 
consisting of knowledge, intelligence relationships, attitudes and abilities of employees, and (3) organisational capital counting internal systems and relations between groups within firm and external environment. Which all source significantly affects SME performance.

a. Labor (Human capital)

Sullivan and Sheffrin (2003) defined human capital as the stock of competences, knowledge and personality attributes embodied in the ability to perform labor so as to produce economic value.

One of the many literatures that study human capital to SME performance empirically found that human capital directly influences SME performance (Tovstiga \&Tulugurova 2007). For the survival and for further growth of SMEs human capital is important because SMEs are more labour-intensive than large companies (Patel \& Conklin, 2012).

b. Labor Cost (Wage)

As SMEs perform better more employment opportunity is created. As well as human capital has positive affect on performance of firms, the cost of labor affect is much debated. According to the competitive model in the longrun wages should depend on worker's skills, not on the performance of firm (Rosen, 1986). The standard bargaining model predicts correlation between wages and firm performance (Helpman, Itskhoki and Redding, 2010). There exists numerous literature on CEO and firm performance correlation but less on below boardroom or ordinary worker.

c. Access to Finance

For many SMEs one of the most difficult situation for growth and survival of start-up SMEs are regarded as access to finance (Mazanai \& Fatoki, 2012). Pretorius \& Shaw (2004) observe that a vast majority of SMEs rely on internal finance, such as contribution from the owners, family and friends, which is often inadequate for SMEs to survive and grow. If finance is essential to SME growth, the affect on the performance is interesting field to study. d. Export

There are scholars who argue that the faster developing SMEs are the ones that likely to be engaged in trade, in import and export activities. Study by Fedex (2015) report on European SMEs showed that SMEs that export are typically more positive about future business performance ( $60 \%$ expect revenue growth in the next year) than those that do not export (48\%). What is the relation between performance of SMEs and direct and indirect export was on our study focus.

\section{Data and Model}

The following section will describe the dataset and methodology used. There is no single consensus on definition of SMEs thus for consistency purpose, used World Bank definition. It classifies that employees of 5-19 small firms, 20-99 employees medium sized firms, 100 or more employees are defined as large firms.

\subsection{Data}

This paper used World Bank Enterprise Survey which is a firm-level survey of a representative sample of economy's private sector. Aim of improving business environment of SMEs, World Bank started systematic collection of enterprise data across countries. The World Bank data collected in Mongolia was conducted between 2012-2013. Of all the enterprises, $183 \mathrm{micro} / \mathrm{small}$ (<20 employees), 141 Medium (20-99 employees), 36 Large (100+employees) were surveyed. Out of all firms 115 firms were in the manufacturing sector, 117 firms in the retail sectors, and 128 firms were categorized as the other service firms but agriculture sector was not included. Also, from all the firms 339 were domestically owned and 21 were foreign owned. Large number of survey participants of the sector were non-exporter 344, and 14 were exporter in the field.

\subsection{Methodology}

Based on the literature above and taking account into Cobb-Douglas production function, quantitative method is used. Multiple regression is conducted. Dependent variable is the economic performance of SMEs. Independent variables are capital, number of labor, cost of labor, age, access to finance, and export. Our estimated model can be written as:

\section{SPERF $=\boldsymbol{f}(\mathrm{CAP}, \mathrm{LAB}$, COSTLAB, AGE, FIN, EXP, $\varepsilon)$}

Where: SPERF is SME economic performance, CAP is physical capital the firms own, LAB is the number of labors the firm had in beginning of establishment, COSTLAB is the total cost of labor, AGE is the establishment since operation, FIN is access to finance, the amount the firm loaned from outside organization, EXP is export how much percentage the firm export in terms of total sales, and $\varepsilon$ is error term. The model given in equation above can be rewritten as:

$$
\mathrm{SPERF}=\beta_{0}+\beta_{1} \mathrm{CAP}+\beta_{2} \mathrm{LAB}+\beta_{3} \mathrm{COSTLAB}+\beta_{4} \mathrm{AGE}+\beta_{5} \mathrm{FIN}+\beta_{6} \mathrm{EXP}+\varepsilon
$$

\section{Result and Discussion}

The following tables first show the multiple regression table result and the following is the correlation table of the 
variables that were examined.

\begin{tabular}{|l|l|l|l|l|}
\hline \multirow{2}{*}{$\mathrm{N}=156$} & \multicolumn{2}{|c|}{ Coefficients } & \multirow{2}{*}{ t } & \multirow{2}{*}{ Sig. } \\
\cline { 2 - 3 } & $\mathrm{B}$ & Std.Error & & \\
\hline constant & 2.49 & 1.73 & 1.44 & 0.151 \\
\hline CAP & 0.18 & 0.067 & 2.75 & 0.007 \\
\hline LAB & -0.008 & 0.001 & -6.33 & 0.000 \\
\hline COSTLAB & 0.69 & 0.089 & 7.83 & 0.000 \\
\hline AGE & 0.0005 & 0.017 & 0.03 & 0.975 \\
\hline FIN & 0.27 & 0.108 & 0.25 & 0.802 \\
\hline EXP & -1.65 & 0.646 & -2.56 & 0.012 \\
\hline
\end{tabular}

Table 1. Model regression result

\begin{tabular}{|c|c|c|c|c|c|c|c|c|}
\hline & & SPERF & CAP & LAB & AGE & COSTLAB & FIN & EXP \\
\hline \multirow{7}{*}{$\begin{array}{l}\text { Pearson } \\
\text { Correlation }\end{array}$} & SPERF & 1.000 & 0.2165 & -0.0337 & 0.0178 & 0.2462 & 0.1836 & -0.0415 \\
\hline & CAP & & 1.000 & 0.1305 & 0.3276 & 0.4426 & 0.097 & -0.0207 \\
\hline & LAB & & & 1.000 & 0.3848 & 0.3644 & 0.2982 & 0.0541 \\
\hline & AGE & & & & 1.000 & 0.4022 & 0.1573 & -0.0800 \\
\hline & COSTLAB & & & & & 1.000 & 0.1653 & 0.0423 \\
\hline & FIN & & & & & & 1.000 & 0.0291 \\
\hline & EXP & & & & & & & 1.000 \\
\hline \multirow{7}{*}{ Sig.(1-tailed) } & SPERF & & 0.0003 & 0.5751 & 0.7668 & 0.000 & 0.0021 & 0.4901 \\
\hline & CAP & & & 0.0293 & 0.000 & 0.000 & 0.106 & 0.7302 \\
\hline & LAB & & & & 0.000 & 0.000 & 0.000 & 0.3683 \\
\hline & AGE & & & & & 0.000 & 0.0085 & 0.1829 \\
\hline & COSTLAB & & & & & & 0.0056 & 0.4819 \\
\hline & FIN & & & & & & & 0.6286 \\
\hline & EXP & & & & & & & \\
\hline $\mathbf{N}$ & 279 & 279 & 279 & 279 & 279 & 279 & 279 & 279 \\
\hline
\end{tabular}

Table 2. Pearson Correlation Matrix

Age and Finance variables are regarded as insignificant that cannot explain the economic performance of SMEs. The insignificance of age variable can be explained as for the selected firms their economic performance or productivity is not affected by how long the firm is established or when it started operating. In practice, most firms lack access to finance, when starting operation, it is hard not to have finance to operate however the estimation of our result show that it does not affect the productivity of the firm or in other words insignificant to access to finance. The most significant variables are labor, cost of labor, capital and export. The more the physical capital and right amount of labor and managing the amount of total cost of labor will bring firms more production, ultimately end with higher economic performance.

In Mongolian case, the economy is relatively small to other countries yet, micro SMEs are rising day by day. For owners of small firm right amount of workers with certain performance and good capital will be helpful for their firms to perform better. Export factor could be important but currently the firms that operate in Mongolia are mainly focused on domestic rather than the export and out of surveyed owners only 14 were exporter in the field. Number of years or in other words how long the firm has operated has nothing do with the performance of the firm. Thus implying newly established firms have hope in having competitive advantage.

\section{Conclusion}

Using the World Bank Enterprise survey this study tried to find answer to what factors influence SME's economic performance. Out of 360 survey results 279 were used but due to some missing variables and no answer sections only 156 results where used in this regression. Overall, for SMEs and MSMEs in order to be productive there is no significant influence from number of years of operation and whether the firm has good access to finance. It only depends on physical capital what machinery and what technique they are using and right number of workers not too many not too less to be productive and how much the firm is paying will be significant factor for employees there whether the firm will be productive or not. After producing while export could be one of the factors that will influence the economic performance of the firm.

The study has several limitations. First the data is the most recent one but was conducted between 2012-2013. Hope more and more researchers and government of Mongolia would collect data on current SMEs in Mongolia available for public research use. Second limitation is that the regression is based on answer of 156 firms in 
Mongolia, and only manufacturing and service sector SMEs were conducted. Third for the answers the managers and owners have had bias, we cannot guarantee the unbiasedness. Hope, in the future more and more scholars study the development of SMEs and study the factors that affect the economic performance from both internal and external side.

\section{References}

Barney, J. (1991). Firm resources and sustained competitive advantage. Journal of Management, 17 (1), 99-120.

Chandler, G. \& Hanks, S. (1 994). Market attractiveness, resource-based capabilities, venture performance and venture performance. Journal of Business Venturing, 9, 331-349.

Covin, J.G. (1991). Entrepreneurial vs. conservative firms: A comparison of strategies and performance. Journal of Management Studies, 25(5), 439-462.

C. Patel, Pankaj \& Conklin, Betty. (2010). Perceived Labor Productivity in Small Firms - The Effects of HighPerformance Work Systems and Group Culture Through Employee Retention. Entrepreneurship Theory and Practice, 36, 205 - 235.

Elhanan Helpman \& Oleg Itskhoki \& Marc-Andreas Muendler \& Stephen J. Redding, 2017. Trade and Inequality: From Theory to Estimation, The Review of Economic Studies, 84(1), 357-405.

FedEx Express (2015) European SME Export Report.

Musara, Mazanai \& Fatoki, Olawale. (2012). Perceptions of Start-up Small and Medium-Sized Enterprises (SMEs) on the Importance of Business Development Services Providers (BDS) on Improving Access to Finance in South Africa. Journal of Social Sciences, 30, 31-41.

Pretorius, M., \& Shaw, G. (2004). Business plans in bank decision-making when financing new ventures in South Africa. South African Journal of Economic and Management Sciences, 7(2),221-241.

Rosen, S. (1986) The Theory of Equalizing Differences. In: Ashenfelter, O.C. and Layard, R., Eds., The Handbook of Labor Economics, Vol. 1, North-Holand, Amsterdam, 641-692.

Teresa C Fort \& John Haltiwanger \& Ron S Jarmin \& Javier Miranda, 2013. How Firms Respond to Business Cycles: The Role of Firm Age and Firm Size, IMF Economic Review, Palgrave Macmillan, 61(3), 520-559,

Tovstiga, G., \&Tulugurova, E. (2007). Intellectual Capital Practices and Performance in Russian Enterprises. Journal of Intellectual Capital, 8(4), 695-707.

Sutton, J. (1997). Gibrat's Legacy. Journal of Economic Literature,35(1), 40-59.

Zahra, S.A. \& George, G. (1999). Manufacturing strategy and new venture performance: A comparison of independent and corporate ventures in the biotechnology industry. The Journal of High Technology Management Research, I 0(2), 313-345. 